\title{
A Rare Form Genetic Abnormality in Turner Syndrome
}

\section{1,2Mariana Cristian Costache Outas, Camelia Procopiuc ${ }^{3}$, Oana Popa ${ }^{3}$, Madalina -Aura Vintila ${ }^{1,3}$, Cosmina-Raluca Costache $^{4} \&$ Danai Stambouli ${ }^{5}$}

1"Carol Davila" University of Medicine and Pharmacy, Bucharest, Romania; ${ }^{2 "}$ Coltea" Clinical Hospital, Bucharest, Romania; ${ }^{3 *} \mathrm{CI}$ Parhon' National Institute of Endocrinology, Bucharest,

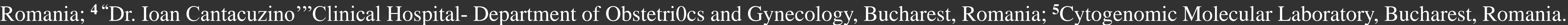

PERSONAL PAST HISTORY

Born premature $(28 \mathrm{w})$, AGA

No significant past history

No recent changes in weight

\section{Examination}

Height $158.3 \mathrm{~cm}(-1.05 \mathrm{SD}), \mathrm{MPH}=161.5 \mathrm{~cm}$. (SD=-0.75 DS)

$\mathrm{W}=51.3 \mathrm{~kg} ., \mathrm{BMI}=19.38 \mathrm{~kg} / \mathrm{m}^{2}$

low-set ears, widely spaced nipples, cubitus valgus

$\mathrm{BP}=110 / 60 \mathrm{mmHg}$ - equal in both arms

Female external genitalia Tanner stage B1P2(A2)

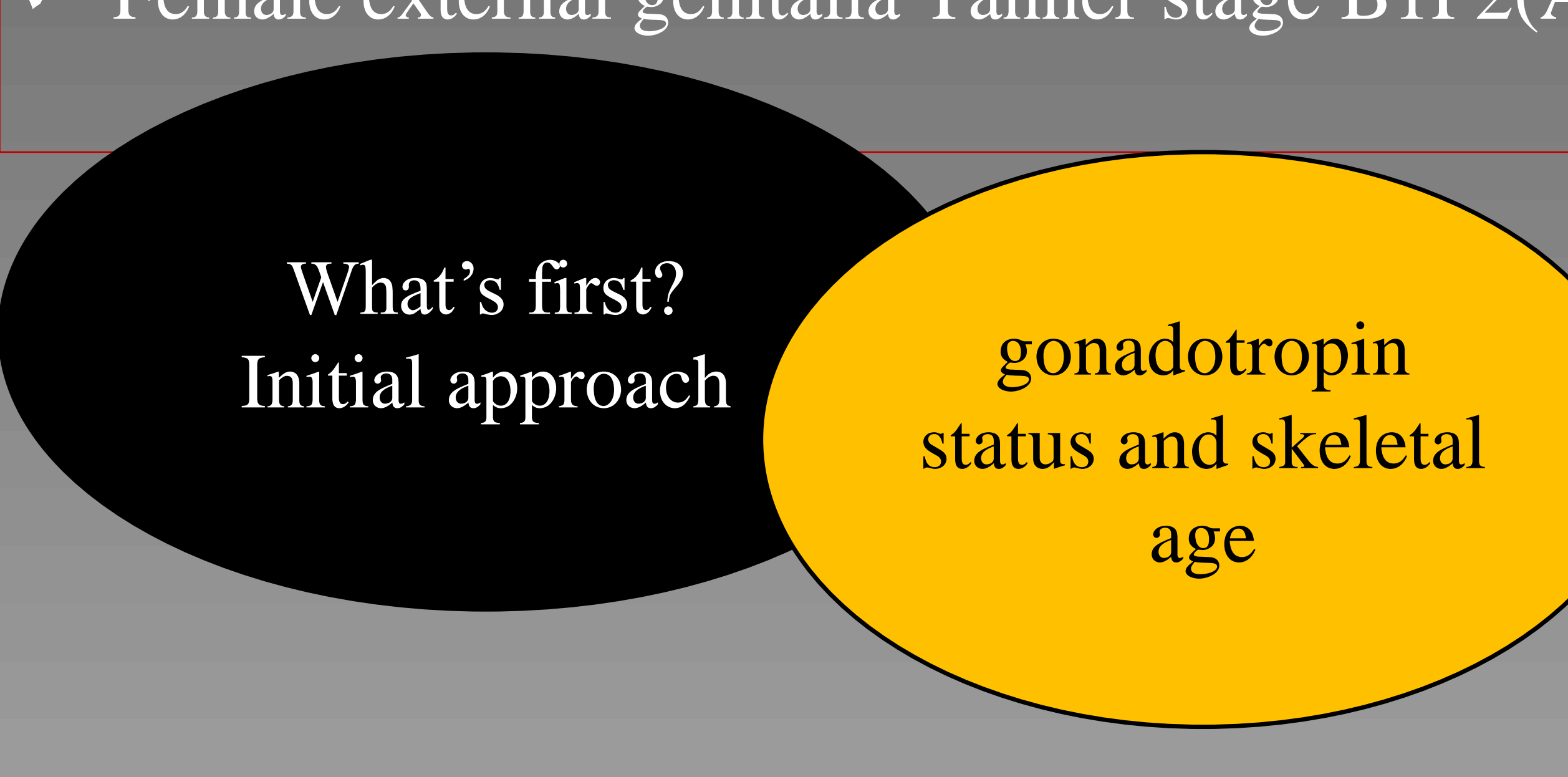

Bone Age Greulich \&Pyle: 15 years

\begin{tabular}{lll} 
Parameter & value & normal range \\
\hline FSH & $65.39 \mathrm{mIU} / \mathrm{mL}$ & $3.5-12.5$ \\
\hline LH & $44.05 \mathrm{mIU} / \mathrm{mL}$ & $2.4-12.6$ \\
\hline E2 & $8.43(\mathrm{pg} / \mathrm{mL})$ & $43.8-211$ \\
\hline testosterone & $0.31 \mathrm{ng} / \mathrm{mL}$ & $0.1-0.75$ \\
\hline AMH & 0.08 & \\
\hline PRL & $16.37 \mathrm{ng} / \mathrm{mL}$ & $4.79-23.3$ \\
\hline fT4 & $11.64 \mathrm{pmoL} / \mathrm{L}$ & $12-22$ \\
\hline TSH & 1.55 & $0.5-4.5$ \\
\hline ATPO & $<10 \mathrm{UI} / \mathrm{mL}$ & $<35$ \\
\hline
\end{tabular}

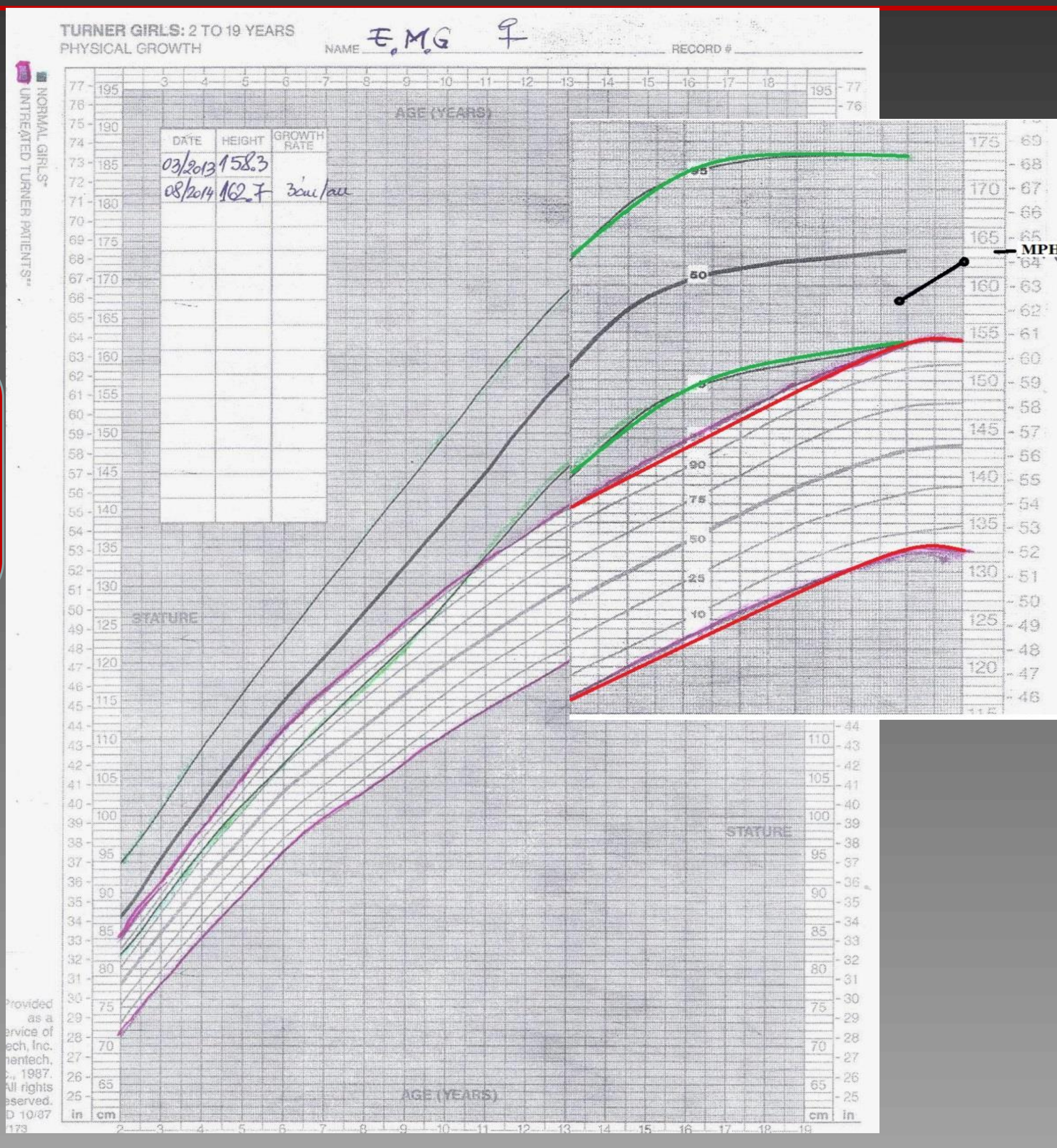

Pelvic US : small uterus $26 / 5.5 \mathrm{~mm}$, undifferentiated endometrium, negative for gonads or pelvic tumors.

Abdominal CT: uterus 1.92 / 1.13 / $1.76 \mathrm{~cm}$. (2 mL); no gonads or abdominal tumors; normal adrenals

Short stature is the most constant clinical finding in Turner Syndrome due to loss of one copy of SHOX gene (located Xp22.33 or Yp11.32)

Karyotype: Turner Syndrome 45X, der $(13 ; Y)(q 10 ; q 10)$

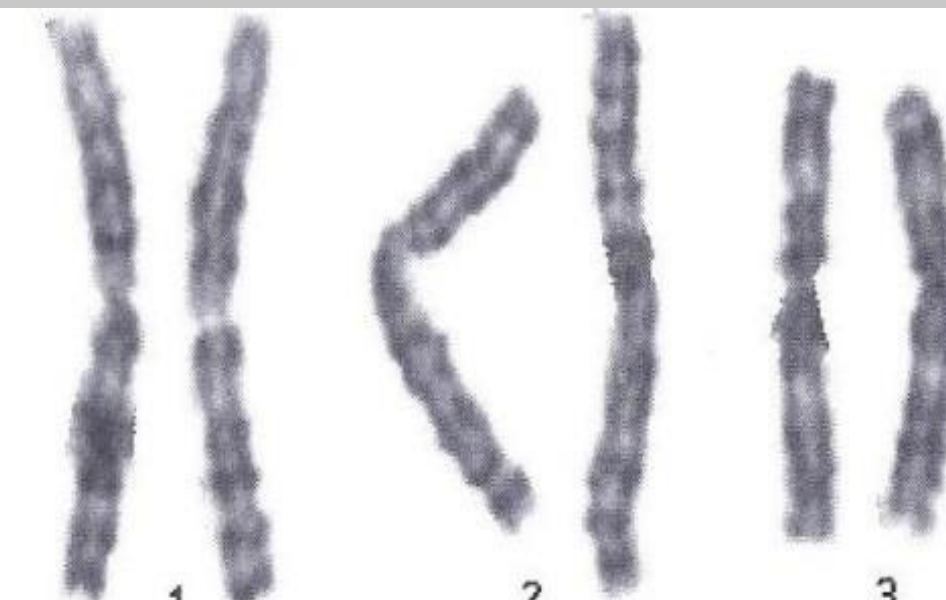

\|\|\|\|\|\|\|\|

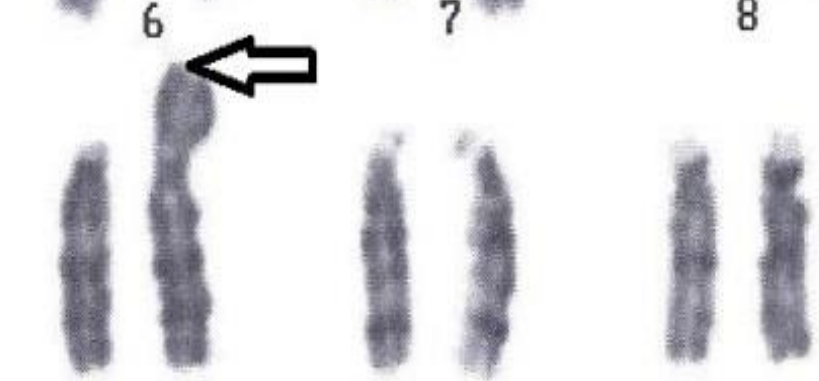

118

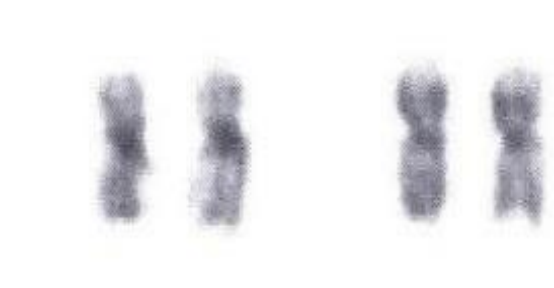

01
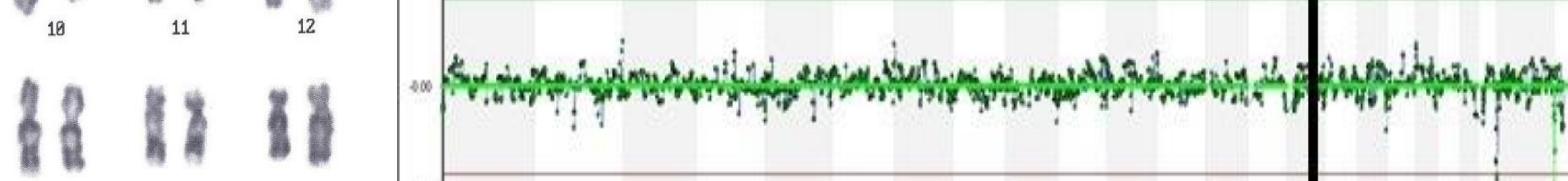

loss of genetic material on $Y$ chromosome

REZULTTAT

Folosind programul Leica CW4000 Karyo s-an studiat 15 metafaze bandate GT

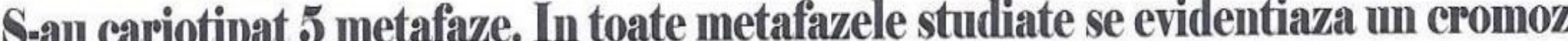
levivativ 13 prin alougrea la brotul o a cestuia de material genetic supliment posibil un cromozom Y, si nu se vizualizeaza un cromozom de sex X. Pentru confi

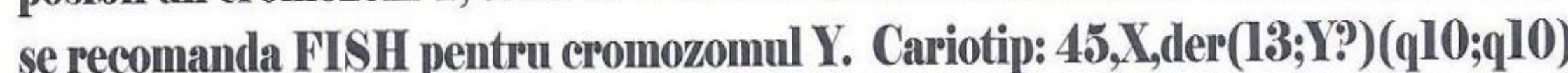

$\operatorname{arrYp11.31(2,565,871-2,871,490x0,3,025,075)}$

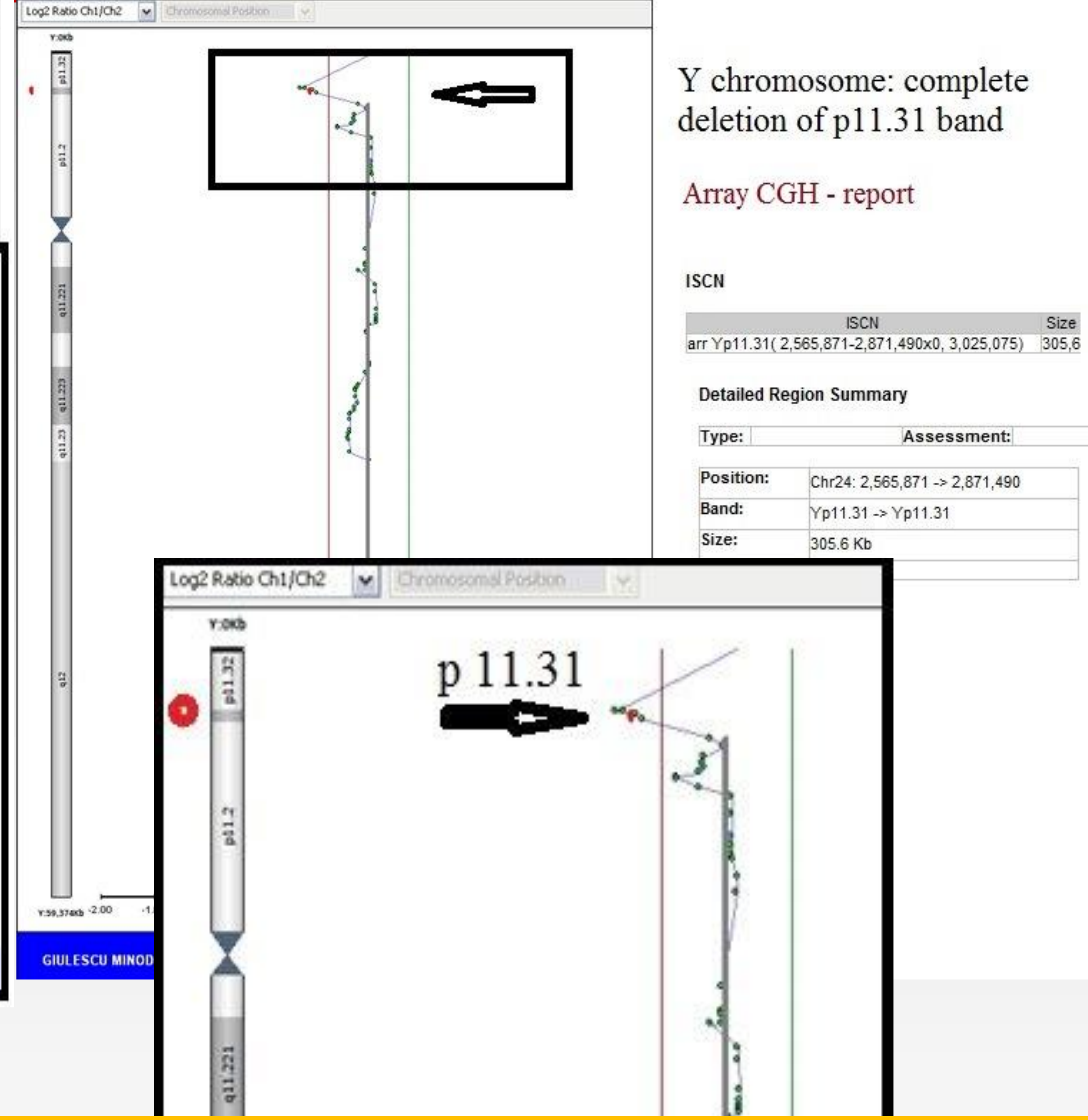

From our knowledge this is the first report of Y-autosome translocation together with SRY deletion in a female phenotype. The classical cytogenetics showed Turner Syndrome together with Y chromosome material. Further investigations were performed because of her normal stature and female phenotype.

$Y$ Ch. specific sequences in karyotype of girls with TS vary from 2\% to 12\%-depending on methodology applied Risk of gonadoblastoma : up to 30\%. Prophylactic gonadectomy is advisable. Genes implicated in gonadoblastoma: TSPY (Yp11.22), POU5F1 (OCT4: 6p21.31). SRY gene (Yp11.31) is not directly implicated in gonadoblastoma 